Research

\title{
hCG Priming Before Ovary Collection Increasing The Oocyte Quality In The Domestic Cat
}

\author{
Karisma Mardatillah', Rini Widyastuti, ${ }^{1,2}$, Diah Nugrahani Pristihadi', Wahyudin', \\ Sigit Prastowo ${ }^{3}$, Asep Gunawan ${ }^{4}$, Arief Boediono' ${ }^{1 *}$ \\ 'Laboratory of Embryology, Department of Anatomy Physiology and Pharmacology, \\ Faculty of Veterinary Medicine, IPB University \\ ${ }^{2}$ Department of Animal Production, Animal Husbandry Faculty, Universitas Padjajaran, Bandung \\ ${ }^{3}$ Department of Animal Science, Faculty of Agriculture, Universitas Sebelas Maret, Surakarta, Indonesia \\ ${ }^{4}$ Department of Animal Production and Technology, Faculty of Animal Science, IPB University \\ *Corresponding author: ab@apps.ipb.ac.id \\ Submitted April 14, 2021 Accepted May 11, 2021
}

\begin{abstract}
Oocyte competence is a determining factor that influences the embryo development. Embryos produced in vitro have a reduced developmental competence than embryos produced in vivo. Therefore, human Chorionic Gonadotropin (hCG) injection was carried out to improve the quality of the oocytes. The objective of this study was to evaluate the effect of ovarian stimulation with hCG before ovary collection on oocyte quality in the domestic cat. Oocyte donors were either 1) treated with a single dose of $200 \mathrm{IU}$ hCG four days before ovary collection (hCG group), or, 2) no treatment before ovary collection (control group). The oocytes were collected by the slicing method. Immature cumulus oophorus complexes (COCs) from both groups were pooled and matured in vitro for 24-26 hours. Then mature oocytes were fertilized with epididymal sperm and cultured in vitro for seven days. The results study showed that the number of the dominant follicle (DF) and the number of COCs in the hCG group was higher than the control group in right and left ovaries $(p<0.05)$. The morulae and blastocyst rates from cleavage embryos were $88 \%$ and $75 \%$, respectively. These results demonstrate that hCG priming of oocytes donors before ovary collection improve oocyte quality.
\end{abstract}

Keywords: hCG, dominant follicle, oocyte quality, embryo, domestic cat

\begin{abstract}
ABSTRAK
Kualitas oosit merupakan faktor penentu yang memengaruhi perkembangan embrio. Embrio yang diproduksi secara in vitro memiliki perkembangan yang lebih rendah daripada embrio yang diproduksi secara in vivo. Oleh karena itu, injeksi hormon human Chorionic Gonadotropin (hCG) dilakukan untuk meningkatkan kulitas oosit. Tujuan penelitian ini adalah mengevaluasi pengaruh pemberian hCG sebelum koleksi ovarium terhadap kualitas oosit pada kucing domestik. Hewan donor dibagi menjadi dua kelompok, yaitu 1) hewan diberikan 200 IU hCG dosis tunggal empat hari sebelum koleksi ovarium (kelompok hCG), dan, 2) hewan tanpa diberikan hCG sebelum koleksi ovarium (kelompok kontrol). Koleksi oosit dilakukan dengan metode slicing. Kompleks kumulus ooforus (COCs) yang belum matang dari kedua kelompok dikumpulkan dan dimatangkan secara in vitro selama $24-26$ jam. Kemudian oosit yang matang difertilisasi dengan sperma epididimis dan dikultur secara in vitro selama tujuh hari. Hasil penelitian menunjukkan bahwa jumlah folikel dominan (DF) dan jumlah COC pada kelompok hCG lebih banyak dibandingkan kelompok kontrol baik pada ovarium kanan maupun kiri $(p<0,05)$. Tingkat perkembangan morula dan blastosis dari embrio cleavage masing-masing adalah $88 \%$ dan $75 \%$. Hasil ini menunjukkan bahwa pemberian hCG pada kucing domestik sebelum koleksi ovarium mampu meningkatkan kualitas oosit.
\end{abstract}

Kata kunci: hCG, folikel dominan, kualitas oosit, embrio, kucing domestik 


\section{INTRODUCTION}

Felidae is a family of mammals in the order Carnivora which consist of at least 36 wild felid species. Human activities reduce forest area where they live in which cause in a decline in number of all worldwide felid species. Based on The International Union for the Conservation of Nature (IUCN) Red List, over half of all wild felids are listed as vulnerable, critically endanger, or endanger, and many have decreasing wild populations. Conservation strategies that can do to maintain population are captive breeding, habitat management and protection, translocation, and reproductive technology. The first breeding program to maintain the existence of wild felid is natural breeding, but many of them cannot reproduce well because of some reasons, for example behavioral incompatibility, infertility, and male aggression (Thongphakdee et al., 2020). Therefore, reproductive biotechnology is an option as conservation strategies and has been explored to increase the number of wild felid populations by saving the genetic materials.

The domestic cat is suitable as animal model for some research about wild felids because of the similarity in anatomy and reproductive characteristic (Lamberski, 2015; Terio et al., 2018). Reproduction technology like in vitro maturation (IVM) of oocyte and in vitro embryo production system are useful technique to save genetic material of domestic cat and several endanger felid species (Pope, 2014; Veraguas et al., 2017). The domestic cat embryo produced in vitro have a reduced developmental competence and arrest at morulae stage than embryo produced in vivo (Roth et al., 1994). This is because embryo development in vitro has incomplete cytoplasmic maturation (Gomez et al., 2000; Bogliolo et al., 2004). Based on that problem, increasing oocyte quality is needed to improve embryo development. In this present study, we want to conduct ovarian stimulation using single dose of $200 \mathrm{IU}$ hCG four days before ovary collection in the domestic cat.

\section{MATERIAL AND METHODS}

Animal in the present study were 16 adult female cats with healthy condition. The animals were kept indoors with room temperature and natural light. The animals fed twice a day and water was available ad libitum. All the experiments in this research and the animal manipulation procedures were approved by the Ethics Committee of the Faculty of Veterinary Medicine, IPB University (Ethical approval number: 022/KEH/SKE/XII/2020).
The present study divided into two groups; 1 ) females were treated with single dose of 200 IU hCG four days before OVH (hCG group) and 2) untreated females before OVH (control group). The bodies of the domestic cats were weighted before $\mathrm{OVH}$ and the ovaries weighted after $\mathrm{OVH}$. The number of corpus luteum (CL) and DF in the ovaries from both groups was counted. The oocytes were collected by the slicing the cortex of ovaries and classified into COCs, degenerated, and spontaneous cleavage oocytes. The Immature COCs from both groups were pooled and matured in vitro for 24-26 hours.

Healthy male cats $>6$ months of age were subjected to orchidectomy. The testis and epididymis were refrigerated at $4{ }^{\circ} \mathrm{C}$ for 24 hours. For IVF, the sperm were collected from caudal portion of epididymis which refrigerated before. The COCs were placed in fertilization medium and co-incubated with sperm for 18 hours. After that, the presumptive zygotes were cultured in vitro for seven days. The rates of cleavage, morulae, and blastocyst development rate were evaluated on day 3 , day 5 , and day 7 , respectively.

The independent t-test was used to evaluate body weight, ovary weight, number of $\mathrm{CL}$, number of DF and quality of oocyte from both groups. Pearson correlation was used to evaluate the correlation of body and ovary weight. All analyses were done using the software Minitab 18. $P<0.05$ indicated statistical differences between groups.

\section{RESULT AND DISCUSSION}

As shown in Table 1, the body weight in the hCG group was similar to the control group. Significant difference was not found in the mean of ovarian weight between both of groups. There were no correlation between body weight and ovarian weight. Based on analysis of control animal data from Bailey et al. (2004), ovary weights are best compared using organ-to-brain weight ratios than using organ-tobody weight ratios. Understanding the relationship between absolute organ weight, body weight, and brain weight as well as which parameter bests predicts a true effect on organ weight will lead to improved organ weight interpretation (Bailey et al., 2004).

The number of $C L$ and DF in the hCG group and control group are shown in Table 2. The number of $\mathrm{CL}$ is not significantly different between two groups in the left and right ovaries. In contrast, the number of DF in the hCG group was higher in the left and the right ovaries than control group ( $p<0.05)$. 
Table 1 Body weight and ovarian weight in the hCG group and control group in the domestic cat

\begin{tabular}{|c|c|c|c|c|c|}
\hline & \multirow[b]{2}{*}{$N$} & \multirow{2}{*}{$\begin{array}{c}\text { Body Weight }(\mathrm{kg}) \\
\quad(\text { mean } \pm \mathrm{SD})\end{array}$} & \multirow{2}{*}{$\begin{array}{l}\text { Ovarium Weight }(\mathrm{g}) \\
\quad(\text { mean } \pm \mathrm{SD})\end{array}$} & \multicolumn{2}{|c|}{ Correlation } \\
\hline & & & & $\begin{array}{c}\text { Pearson Correla- } \\
\text { tion }\end{array}$ & P-value \\
\hline hCG & 8 & $2.79 \pm 0.55^{a}$ & $0.41 \pm 0.12^{\mathrm{a}}$ & -0.338 & 0.413 \\
\hline Control & 8 & $2.84 \pm 0.37^{a}$ & $0.31 \pm 12^{\mathrm{a}}$ & -0.563 & 0.146 \\
\hline
\end{tabular}

Table 2 The number of corpus luteum and dominant follicle in hCG group and control group in the domestic cat

\begin{tabular}{cccccc}
\hline & & \multicolumn{2}{c}{ Number of corpus luteum } & \multicolumn{2}{c}{ Number of dominant follicle } \\
\cline { 3 - 6 } & $\mathrm{N}$ & Right & Left & Right & Left \\
& & $($ mean \pm SD $)$ & $($ mean \pm SD $)$ & $($ mean \pm SD) & (mean \pm SD) \\
\hline hCG & 8 & $0.88 \pm 1.13^{\mathrm{a}}$ & $0.75 \pm 0.89^{\mathrm{a}}$ & $6.13 \pm 2.90^{\mathrm{a}}$ & $4.25 \pm 3.81^{\mathrm{a}}$ \\
Control & 8 & $1.13 \pm 1.89^{\mathrm{a}}$ & $0.13 \pm 0.35^{\mathrm{a}}$ & $0.25 \pm 0.71^{\mathrm{b}}$ & $0.13 \pm 0.35^{\mathrm{b}}$ \\
\hline
\end{tabular}

COCs from hCG and control group were matured for 24 hours. Mature oocyte in both of group had expanded cumulus cells (CCs), but CCs in the hCG group was better and had more layers than in the control group. Mature oocyte from both groups were pooled then fertilized with epididymal sperm. The morulae and blastocyst rates from cleavage embryos were $88 \%$ and $75 \%$, respectively. It indicates that administration single dose of hCG could improve oocyte competence in domestic cat. hCG is well known causing oocyte maturation and ovulation in felids (Wildt et al., 1998; Howard, 1999), but it also can cause secondary follicular growth (Swanson et al., 1997; Wildt et al., 1978).

CCs that surrounded oocyte have positive impact in oocyte competence. There is bi-directional communication exist between oocyte and CCs which is essential for the production of oocyte competence (Huang \& Wells, 2010). CCs are biologically distinct from other follicular cells and perform specialized roles, transmitting signals within the ovary and supporting oocyte growth and maturation during the later stages of follicular development through metabolites produced and secreted through the gap junction mechanism to the oocyte cells (Macaulay et al., 2016; Huang \& Wells, 2010).

According to Bilodeau-Goeseels \& Panich (2002), oocyte with CCs more than five layer reaches a higher number of cell division than oocytes with less than five CCs layers. Furthermore, Kakkassery et al.
2010), stated that greater the number of CCs, greater was the maturation rate. Oocytes with more than three layers of CCs exhibited significantly higher maturation rate than the denuded oocytes and oocytes with partial cumulus layers.

"All authors declare that there are no conflicts of interest".

\section{REFERENCE}

Bailey SA, Zidell RH, Perry RW. 2004. Relationships between organ weight and body/brain weight in the rat: what is the best analytical endpoint?. Toxicologic Pathology 32(4): 448-466.

Bilodeau-Goeseels S, Panich P. 2002. Effects of oocyte quality on development and transcriptional activity in early bovine embryos. Animal Reproduction Science 71(3-4): 143-155.

Bogliolo L, Leoni G, Ledda S, Zedda, MT, Bonelli P, Madau L, Santucciu S, Naitana A, Pau S. 2004. Mphase promoting factor (MPF) and mitogen activated protein kinases (MAPK) activities of domestic cat oocytes matured in vitro and in vivo. Cloning \& Stem Cells. 6(1): 15-23.

Gomez MC, Pope CE, Harris R, Davis A, Mikota S, Dresser BL. 2000. Births of kittens produced by intracytoplasmic sperm injection of domestic cat 
oocytes matured in vitro. Reproduction, Fertility and Development 12(8): 423-433.

Howard JG. 1999. Assisted Reproductive Techniques in Nondomestic Carnivores. In: Fowler ME, Miller RE (eds). Zoo and Wild Animal Medicine: Current Therapy IV. Philadelphia: WB Saunders Co. p449-457.

Huang Z, Wells D. 2010. The human oocyte and cumulus cells relationship: new insights from the cumulus cell transcriptome. Molecular Human Reproduction 16(10): 715-725.

Kakkassery MP, Vijayakumaran V, Sreekumaran T. 2010. Effect of cumulus oocyte complex morphology on in vitro maturation of bovine oocytes Journal of Veterinary and Animal Sciences. 41: 12-17

Lamberski N. 2015. Felidae. In: Fowler ME, Miller RE (eds). Fowler's Zoo and Wild Animal Medicine. $8^{\text {th }}$ ed. Philadelphia: WB Saunders Co. p467.

Macaulay AD, Gilbert I, Scantland S, Fournier E, Ashkar F, Bastien A, Saadi HA, Gagné D, Sirard MA, Khandjian ÉW, Richard FJ. 2016. Cumulus cell transcripts transit to the bovine oocyte in preparation for maturation. Biology of Reproduction 94(1): 16-21.

Pope CE. 2014. Aspects of in vivo oocyte production, blastocyst development, and embryo transfer in the cat. Theriogenology 81(1): 126-137.

Roth TL, Swanson WF, Wildt DE. 1994. Developmental competence of domestic cat embryos fertilized in vivo versus in vitro. Biology of Reproduction 51(3): 441-451.

Swanson WF, Wolfe BA, Brown JL, Martin-Jimenez T, Riviere JE, Roth TL, Wildt DE. 1997. Pharmacokinetics and ovarian-stimulatory effects of equine and human chorionic gonadotropins administered singly and in combination in the domestic cat. Biology of Reproduction. 57(2): 295-302.

Terio KA, McAloose D, Mitchell E. 2018. Felidae. In: Terio KA, McAloose D, Leger JS. Pathology of Wildlife and Zoo Animals. Cambridge: Elsevier Inc. p263.

Thongphakdee A, Sukparangsi W, Comizzoli P, Chatdarong K. 2020. Reproductive biology and biotechnologies in wild felids. Theriogenology. 150: 360-373.

Veraguas D, Echeverry D, Castro FO, RodriguezAlvarez L. 2017. Applied biotechnologies in the conservation of wild felids: In vitro embryo production and cellular regenerative therapies. In Shrivastav AB (eds). Big cats. InTech. London.

Wildt DE, Brown JL, Swanson WF. 1998. Cats. In: Knobil E, Neill JD (eds). Encyclopedia of Reproduction. Academic Press. New York. p497-510.

Wildt DE, Guthrie SC, Seager SW. 1978. Ovarian and behavioral cyclicity of the laboratory maintained cat. Hormones and Behavior 10(3): 251-257 